\title{
The effect of using Functional training exercises on some physical abilities, lower limbs kinematics and skill level performance on le Petit Echappe' in ballet
}

\section{-Hany Abdelaziz Saleh}

\author{
- Rwida Salah Ahmed
}

\section{1/0 Introduction:}

Hany Abdelaziz (2018) (8), and D, Gordon E, Robertson, Gary Kamen, Graham E, Caldwell, Joseph Hamil, Saunders-N, Whittlesey: (2004) (14) indicate that dynamic performance requires many Of the special skills and each skill includes a set of performances and that the most effective way to improve and develop performance is the kinetic analysis where it requires determining the correct mechanical performance for the skill.

Fabio Comana (2004) (18), and Gehan Elsawy (2010) (19) state that functional strength training is a mixture of strength and balance training performed simultaneously, and that balance is a key component of functional training.

On the difference between qualitative and job training, Christine Cunningham (2000) (12), Dave, S (2003) (16), and Da Silva-Grigoletto, Marzo \& Resende-Neto, Antônio \& Teixeira, Cauê, (2010) (15) point out. that functional exercises are exercises that lead to movements and are specialized in studying and following the motor path of the working muscles, while specific exercises lead to muscles specific to the nature of performance.

Zain Nassar (2008) (3), Laws, K., \& Sugano, A (2008) (27), and Pakes, Anna are mentioned. (2020) (30) The ballet is a theatrical performance in which group and individual dance and kinematic performances take place, with musical or lyrical accompaniment, or with percussion instruments, using appropriate clothes, scenery, and lighting. The ballet display is the result of engineering thinking in my space, and the instrument he uses is the body of the dancer himself, and he maintains balance to be able to hold in any special position or during movement.

Safia Mohy El-Din and Samia Mohamed (2012) (5) indicate that the jump is of great importance in the ballet and the student flies in the air to perform a movement with air before landing.

The skill Pas Echappe' is divided into three types:

- Echappe' Sur Les Pointes

- Le Petit Echappe'

- Le Grand Echappe'

Le Petit Echappe' is a very demanding skill for controlling the muscles of the legs, which requires a long period of training.

Grossman, G., \& Phelps, T. (2015) (21), and Homans, J. (2011) (23) see that Le Petit Echappe from the fifth position of the feet. Right front - the knees bent - Arms first position) the student pushes the ground to rise high with the legs open to take the second position in the air. With the knees and the knuckles fully extended, then landing in the fifth position - the left foot in front and the knees bent.

\footnotetext{
Assistant Professor in Sports Training and Movement Science Department, Faculty of Physical Education for (Men Girls) in Port-Said, Port-Said University, Seconded to work as Associate Professor in Physical Education \& Movement Science Department, Al Qassim University, Saudi Arabia

Doctor at the Exercise theories and applications of Exercise, Gymnastics, sports presentations Dep Faculty of Physical Education for (Men - Girls) in Port-Said, Port-Said University.
} 


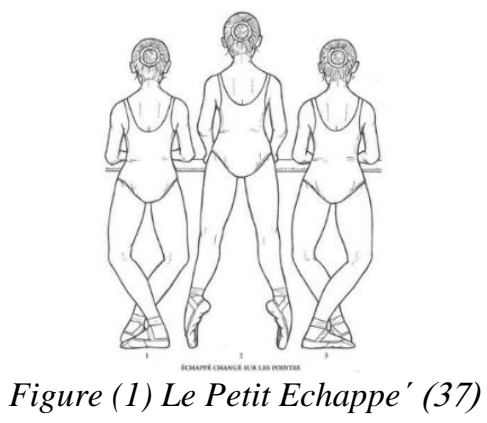

\section{2/0 Research importance and problem:}

The subject of kinetic expression is one of the basic courses in which specialization is made by students of the fourth level in the college, where the performance of female students is assessed by kinematic sentences consisting of a set of interconnected and chained skills, and through the researchers teaching at the Faculty of Physical Education (boys - girls) Port Said and informing them of the results of the evaluation of female students in the past years, especially the ballet committee, have noticed the low grades of female students in jumping skills as they are among the skills that require special specifications, capabilities, and preparations for female students.

Le Petit Echappe' skill is considered one of the most difficult leaps in ballet, which requires controlling the muscles of the legs, in particular, thereby losing the skill and the motor sentence as a whole. Understudy, the researchers sought to use functional strength training in developing the Le Petit Echappe' skill performance in ballet through a codified group of exercises and relying on kinematic analysis in skill analysis as an effective means of measurement, which may reach the students to perform the skill most appropriately. This is what serves theoretical and practical aspects in the field of ballet and those in charge of the education and training process.

\section{3/0 Research Goals:}

This study aims to improve the level of performance of Le Petit Echappe' skill in ballet by:

3/1 develop a set of functional strength training for skill chaos Le Petit Echappe' in ballet. And knowing the extent of its influence on the level of performance of the skill Le Petit Echappe in ballet using dimensional measurement.

$3 / 2$ identifying the percentage of improvement in the skill of Le Petit Echappe in ballet in both components of functional strength and kinematic parameters.

\section{4/0 Research Hypothesis:}

4/1 there are statistically significant differences between the pre and post measurements in each of the components of functional strength and the level of skill performance understudy during.

4/2 there are differences between the pre and post measurements in each of the kinematical parameters for the performance of the skill under study.

\section{5/0 Terms and Symbols used in the study: 5/1 Terms used in the study:}

- Functional strength training:

Ron, J (2005) (33) and Osama Abdel Rahman Ali (2008) (29) define it as "integrated, multi-level movements that include acceleration, stabilization, and deceleration to improve kinetic power, central strength, and neuromuscular efficiency ." 


\section{- Pas Echappe' :}

"One of the ballet fastnesses that needs to be superior in the muscles of the legs is where the feet are bounced together and then landed on them."

\section{- Ballet:}

Ahmed Jumaa (2005) (1) defines him: "Ballet is that integrated art that performs with specific movements in a specific place and by people trained and at a rhythm to express an idea or a story."

\section{5/2 Symbols used in the study:}

\begin{tabular}{ll} 
& \multicolumn{1}{c}{ Terms } \\
- & Time \\
- Horizontal displacement Component \\
- Vertical displacement Component \\
- Absolute displacement \\
- Horizontal Velocity \\
- Vertical Velocity \\
- Absolute Velocity \\
- Horizontal Acceleration \\
- Vertical Acceleration \\
- Absolute Acceleration \\
- angle
\end{tabular}

$\begin{array}{cc}\text { Symbol } & \text { measuring unit } \\ \mathrm{t} & \mathrm{Sec} \\ \mathrm{Dx} & \mathrm{Cm} \\ \mathrm{Dy} & \mathrm{Cm} \\ \mathrm{Dr} & \mathrm{Cm} \\ \mathrm{Vx} & \mathrm{Cm} / \mathrm{sec} \\ \mathrm{Vy} & \mathrm{Cm} / \mathrm{sec} \\ \mathrm{Vr} & \mathrm{Cm} / \mathrm{sec}^{2} \\ \mathrm{Ax} & \mathrm{Cm} / \mathrm{sec}^{2} \\ \mathrm{Ay} & \mathrm{Cm} / \mathrm{sec}^{2} \\ \mathrm{Ar} & \mathrm{Cm} / \mathrm{sec}^{2} \\ \text { ang } & \text { degree }\end{array}$

\section{6/0 Research Procedures:}

\section{6/1 Research Methodology} the study.

The researchers used the descriptive method using the survey method to suit the nature of

\section{6/2 Research Simple:}

The primary study sample was chosen intentionally from the fourth-year students at the Faculty of Physical Education Boys - Girls in Port Said and the sample included (5) students, and the researchers used a number (22) students from the same study community and outside the basic study sample, including (20) students to conduct Scientific transactions (honesty - consistency) of the tests used, as well as two (2) students to conduct the exploratory study to codify the training loads for the proposed job strength training.

Table 1. The Description of research sample $(n=5)$

\begin{tabular}{c|c|c|c|c|c|c}
\hline \hline \multicolumn{2}{c|}{} & \multicolumn{2}{c|}{$\begin{array}{c}\text { Measurement } \\
\text { Unit }\end{array}$} & Mean & $\begin{array}{c}\text { standard } \\
\text { deviation }\end{array}$ & $\begin{array}{c}\text { torsion } \\
\text { coefficient }\end{array}$ \\
\hline \hline \multirow{3}{*}{$\begin{array}{c}\text { Growth } \\
\text { rates }\end{array}$} & 1 & Tall & $\mathrm{Cm}$ & 174 & 0.707 & 0.000 \\
\cline { 2 - 7 } & 2 & Wight & $\mathrm{Kg}$ & 64.2 & 0.836 & $0.512-$ \\
\cline { 2 - 7 } & 3 & Age & Month & 240.8 & 0.836 & 0.512 \\
\hline \hline \multirow{3}{*}{$\begin{array}{c}\text { Physical } \\
\text { tests }\end{array}$} & 1 & Training age & Number & 7.2 & 0.273 & $0.609-$ \\
\cline { 2 - 8 } & 2 & Vertical ability to jump & Number & 7.3 & 0.273 & 0.609 \\
\cline { 2 - 8 } & 4 & Endure strength & Number & 7.6 & 0.418 & $0.512-$ \\
\hline \hline
\end{tabular}

From Table (1) it is clear that the values of the torsion coefficient for each of these variables (understudy) have been limited to $( \pm 3)$, which indicates the moderation of the iterative curve of the study sample in these variables. 
6/3 Data collection tools:

5/3/1 Biomechanics Data collection tools:

Capture, 3D Video by Gopro hero4 black Camera (240fbs)

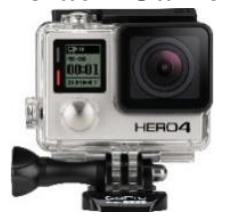

Figure (2) Gopro hero4 black

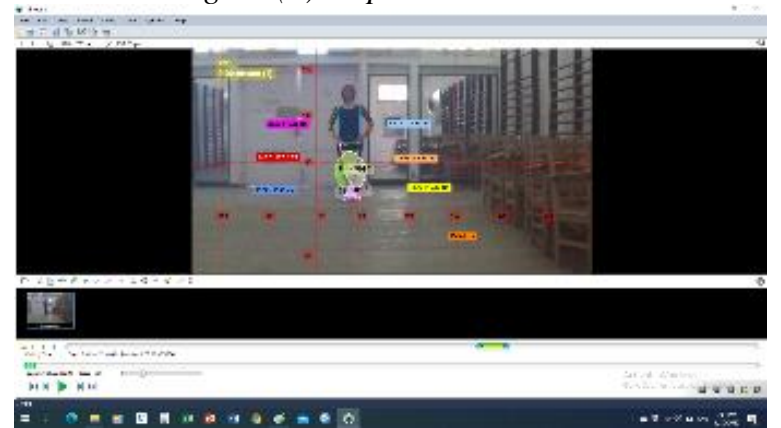

Figure (3) Kinovea

\begin{tabular}{||c|c|c||}
\hline \multicolumn{3}{|c||}{ Petit Echappe' Phases } \\
\hline Phase1 & Phase2 & Phase3 \\
\hline & & \\
\hline Time & Time & Time \\
$\mathrm{t}$ & $\mathrm{t}$ & $\mathrm{t}$ \\
\hline $\begin{array}{c}\text { Displacement } \\
\mathrm{x} y \mathrm{r}\end{array}$ & Displacement & Displacement \\
\hline Velocity & Velocity & Velocity \\
$\mathrm{x} \mathrm{y} \mathrm{r}$ & $\mathrm{x} \mathrm{y} \mathrm{r}$ & $\mathrm{x} \mathrm{y} \mathrm{r}$ \\
\hline $\begin{array}{c}\text { Acceleration } \\
\mathrm{x} y \mathrm{r}\end{array}$ & Acceleration & Acceleration \\
\hline Angles & An y r & x y r \\
ang & ang & Angles \\
\hline
\end{tabular}

Figure (4) Kinematical Model

\section{6/3/2 Anthropometric Data collection tools}

The means and tools for data collection that is appropriate to the nature of the study were identified by looking at the scientific references, research and previous studies in the field of ballet training, and the researcher has used the following tests, measures, and devices:

- Restmeter to measure the total length of the body.

- Medical balance device to measure the mass of the player.

6/3/3 Measurement of functional strength components to perform the skill under study:

The researchers conducted a survey study of some scientific references and previous studies that were made in the field of ballet that they were able to obtain to determine the components of the functional strength to perform the skill under discussion, and the findings of the researchers were presented through an expert opinion poll form to determine the most important components of the functional strength to perform the skill Le Petit Echappe' in ballet and appropriate tests to measure each of them that are appropriate to the age of the study sample. 


\section{6/3/4 scientific coefficients for the tests used:}

The researchers conducted scientific transactions for the tests used understudy to ensure their validity by calculating the validity and reliability coefficients for these tests as follows:

\section{6/3/4/1 Honesty:}

The honesty of the tests used (understudy) was calculated using the honesty of differentiation by a group of students without the primary sample, one of them is distinct, and the other is less distinguished, the strength of each of them is 5 female students, on Sunday 6/1/2019, and the results indicated the availability of honesty for the tests Used.

Table 2. Differentiation validity coefficients for the tests used

\begin{tabular}{|c|c|c|c|c|c|c|c|c|c|}
\hline & & \multirow[b]{2}{*}{$\begin{array}{l}\text { measuring } \\
\text { unit }\end{array}$} & \multicolumn{2}{|c|}{ distinct Group } & \multicolumn{2}{|c|}{$\begin{array}{c}\text { non-distinct } \\
\text { Group } \\
\end{array}$} & \multirow[b]{2}{*}{$\mathrm{T}$} & \multirow[b]{2}{*}{$\mathrm{U}$} & \multirow[b]{2}{*}{$\begin{array}{c}\text { Significance } \\
\text { level }\end{array}$} \\
\hline & & & $\begin{array}{c}\text { Mean } \\
\text { of } \\
\text { Ranks }\end{array}$ & $\begin{array}{c}\text { Sum } \\
\text { of } \\
\text { Ranks }\end{array}$ & $\begin{array}{c}\text { Mean } \\
\text { of } \\
\text { Ranks }\end{array}$ & $\begin{array}{c}\text { Sum } \\
\text { of } \\
\text { Ranks }\end{array}$ & & & \\
\hline 1 & Vertical ability to jump & degree & 3.00 & 15.00 & 8.00 & 40.00 & 2.739- & 0.000 & $0.006^{\text {舫 }}$ \\
\hline 2 & Endure strength & degree & 3.00 & 15.00 & 8.00 & 40.00 & $2.739-$ & 0.000 & $0.006^{\circ}$ \\
\hline 3 & Instep test & degree & 3.0 & 16.00 & 7.80 & 39.00 & $2.471-$ & 1.000 & $0.013^{\text {我 }}$ \\
\hline 4 & $\begin{array}{c}\text { Jump test and balance } \\
\text { over marks }\end{array}$ & degree & 3.0 & 16.00 & 7.80 & 39.00 & $2.471-$ & 1.000 & $0.013^{\text {曹 }}$ \\
\hline
\end{tabular}

It is clear from Table (2) that there are statistically significant differences between the two distinct and non-distinct groups in the tests (understudy) in favor of the distinct group, as the calculated value of $(T)$ is less than the value of $(0.05)$, which indicates the validity of the tests.

\section{6/3/4/2 consistency:}

To determine the consistency of the tests used understudy, the researcher applied the tests to a number (10) students from outside the basic study sample and from the same study community (the exploratory sample), then it was re-applied with an interval of one week between the first and second applications to find the correlation coefficients (Spearman) between the two measurements the first and the second.

Table 3. Stability coefficients for the tests used

$N=(10)$

\begin{tabular}{c|c|c|c|c|c|c|c}
\hline \hline & & \multirow{2}{*}{$\begin{array}{c}\text { measuring } \\
\text { unit }\end{array}$} & \multicolumn{2}{|c|}{$\begin{array}{c}\text { The first } \\
\text { application }\end{array}$} & \multicolumn{2}{|c|}{$\begin{array}{c}\text { The second } \\
\text { application }\end{array}$} & \multirow{2}{*}{$\mathrm{R}$} \\
\cline { 4 - 7 } & & & $\mathrm{M}$ & $\mathrm{Std}$ & $\mathrm{M}$ & $\mathrm{Std}$ & \\
\hline \hline 1 & Vertical ability to jump & degree & 7.2 & 0.27 & 7.1 & 0.22 & 0.272 \\
\hline 2 & Endure strength & degree & 7.3 & 0.27 & 7.2 & 0.27 & 0.789 \\
\hline 3 & Instep test & degree & 7.6 & 0.41 & 7.5 & 0.50 & 0.685 \\
\hline 4 & Jump test and balance over marks & degree & 7.6 & 0.41 & 7.4 & 0.54 & 0.619 \\
\hline \hline
\end{tabular}

It is clear from Table (3) that there is a positive correlation between the first application and the second application in the tests understudy, as the calculated value of $(t)$ is greater than the value of the table $(\mathrm{t})$, which indicates that the test has a high degree of stability.

\section{6/4 Pilot Study:}

The two researchers conducted an exploratory study to identify the conditions and problems that the researcher might face during the basic study, and it was implemented on 
Thursday 10/1/2019, at the Faculty of Physical Education Boys - Girls in Port Said. The pilot study was conducted on one student. The survey aimed to identify:

- Dimensions and frequencies for cameras.

- Visibility through cameras to facilitate later analysis.

And the pilot study achieved its objectives.

\section{6/5 Basic study:}

The basic study was carried out during the period from Sunday, 20/1/2019 to Tuesday $30 / 4 / 2019$, and pre-filming took place on Tuesday 15/1/2019. The post-photography was done on Monday 10/6/2019 at the headquarters of the Faculty of Physical Education for Boys - Girls in Port Said.

\section{6/6 Statistical Treatments}

The researcher used the program (Statistical Package for Social Science) (SPSS 20) in the processing of data statistically using the appropriate statistical coefficients of the study.

\section{7/0 Results:}

\section{7/1 Present the results:}

This chapter includes presenting and discussing the results by studying the differences in the results of the functional strength components tests and the level of performance and kinematic analysis, in light of the data and results of the pre and post measurements of the variables under study on the sample and based on the results of the statistical analysis that are consistent with the nature of the current study. In light of the hypotheses of the study, the two researchers will present the following results:

7/1/1 Display data for functional strength components and performance level: 7/1/1/1 The averages of the components of functional strength and performance level for the pre and post measurements of the study sample:

Table 4. The average score of the research sample in terms of functional strength and performance level

\begin{tabular}{c|c|c|c|c|c|c|c|c|c|c}
\hline \hline & \multicolumn{2}{|c|}{ Ability } & \multicolumn{2}{c|}{$\begin{array}{c}\text { Strength } \\
\text { endurance }\end{array}$} & \multicolumn{2}{c|}{ Static Balance } & \multicolumn{2}{c|}{$\begin{array}{c}\text { Dynamic } \\
\text { Balance }\end{array}$} & \multicolumn{2}{c}{$\begin{array}{c}\text { Level of } \\
\text { performance }\end{array}$} \\
\cline { 2 - 11 } & Before & After & Before & After & Before & After & Before & After & Before & After \\
\hline $\begin{array}{c}\text { The average score of } \\
\text { the research sample }\end{array}$ & 7.2 & 9.1 & 7.3 & 8.9 & 7.6 & 8.7 & 7.6 & 8.7 & 5.7 & 9.1 \\
\hline \hline
\end{tabular}

It is clear from Table (4) that the mean scores for the research sample in the ability of the Before measurement were (7.2 degrees) and the after measurement was (9.1 degrees), and the mean degrees of Strength endurance in the Before measurement (7.3 degrees) and the after were (8.9 degrees) and the average degrees The Static Balance in the Before measurement was (7.6 degrees), in the after it was (8.7 degrees), the average Dynamic Balance levels in the Before measurement were (7.6 degrees) and in the after was ( 8.7 degrees) and the average Level of performance in the before measurement (5.7 degrees) and the after It was (9.1 degrees). 


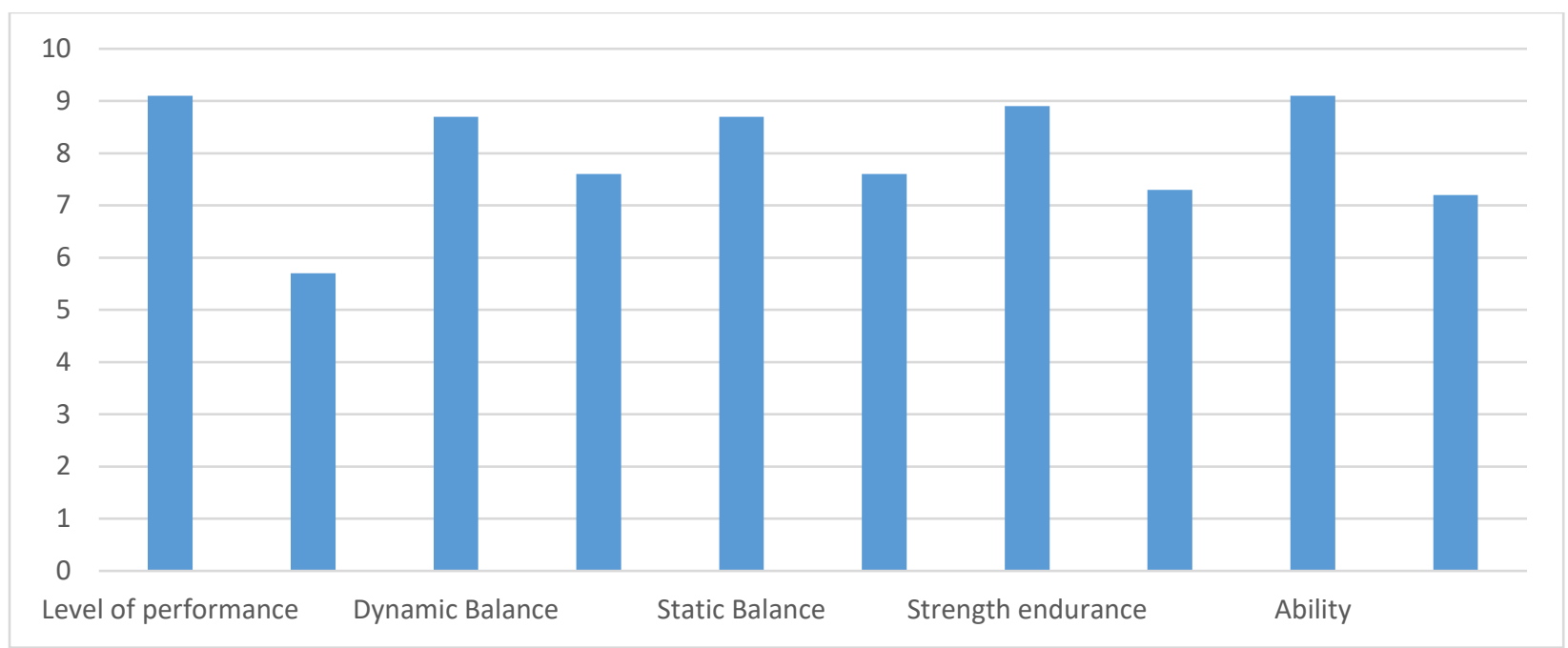

Figure (5) Average score of the research sample in terms of functional strength and performance level

7/1/1/2 An indication of the differences between the pre and post measurements in the components of functional strength and the level of performance of the study sample:

Table 5. Wilcoxon test to indicate differences between pre and post measurements of functional strength components and level of performance

\begin{tabular}{|c|c|c|c|c|c|c|c|}
\hline & \multicolumn{2}{|c|}{ Mean of Ranks } & \multicolumn{2}{|c|}{ Sum of Ranks } & \multirow{2}{*}{$\mathrm{Z}$} & \multirow{2}{*}{ Significance level } \\
\hline & & - & + & - & + & & \\
\hline 1 & Ability & 0.00 & 3.00 & 0.00 & 15.00 & -2.121 & 0.034 \\
\hline 2 & Strength endurance & 0.00 & 3.00 & 0.00 & 15.00 & -2.121 & 0.034 \\
\hline 3 & Static Balance & 0.00 & 3.00 & 0.00 & 15.00 & -2.060 & $0.039^{\text {娄 }}$ \\
\hline 4 & Dynamic Balance & 0.00 & 3.00 & 0.00 & 15.00 & -2.032 & 0.042 \\
\hline 5 & Level of performance & 0.00 & 3.00 & 0.00 & 15.00 & $2.032-$ & $0.042^{\star}$ \\
\hline
\end{tabular}

(*) Signifies the presence of statistically significant differences at the level of significance $(0.05)$

It is clear from Table (5) that there are statistically significant differences between the pre and post measurements in favor of the post-measurement, where the value of the significance level was limited between (0.039 and 0.043) which is less than (0.05) and therefore it is statistically significant.

7/1/1/3 The percentage of improvement between the pre and post measurements in the components of functional strength and the level of performance of the study sample

Table 6. The percentage of improvement between the pre and post measurements in the components of functional strength and the level of performance of the study sample

\begin{tabular}{c|c|c|c|c|c}
\hline & $\begin{array}{c}\text { Average } \\
\text { measurement } \\
\text { (Before) }\end{array}$ & $\begin{array}{c}\text { Average } \\
\text { measurement } \\
\text { (After) }\end{array}$ & $\begin{array}{c}\text { The difference } \\
\text { between the two } \\
\text { mediums }\end{array}$ & $\begin{array}{c}\text { Improvement } \\
\text { rate }\end{array}$ \\
\hline \hline 1 & Ability & 7.2 & 9.1 & 1.9 & $20.9 \%$ \\
\hline 3 & Strength endurance & 7.3 & 8.9 & 1.6 & $18 \%$ \\
\hline 4 & Static Balance & 7.6 & 8.7 & 1.1 & $13 \%$ \\
\hline 5 & Lynamic Balance & 7.6 & 8.7 & 1.1 & $13 \%$ \\
\hline \hline
\end{tabular}

It is clear from Table (6) that the percentage of improvement between the pre and post measurements of the components of the functional strength of the experimental group was in favor of the post-measurement, where the improvement ratio was limited to $(23.71 \%, 32.94 \%)$. 


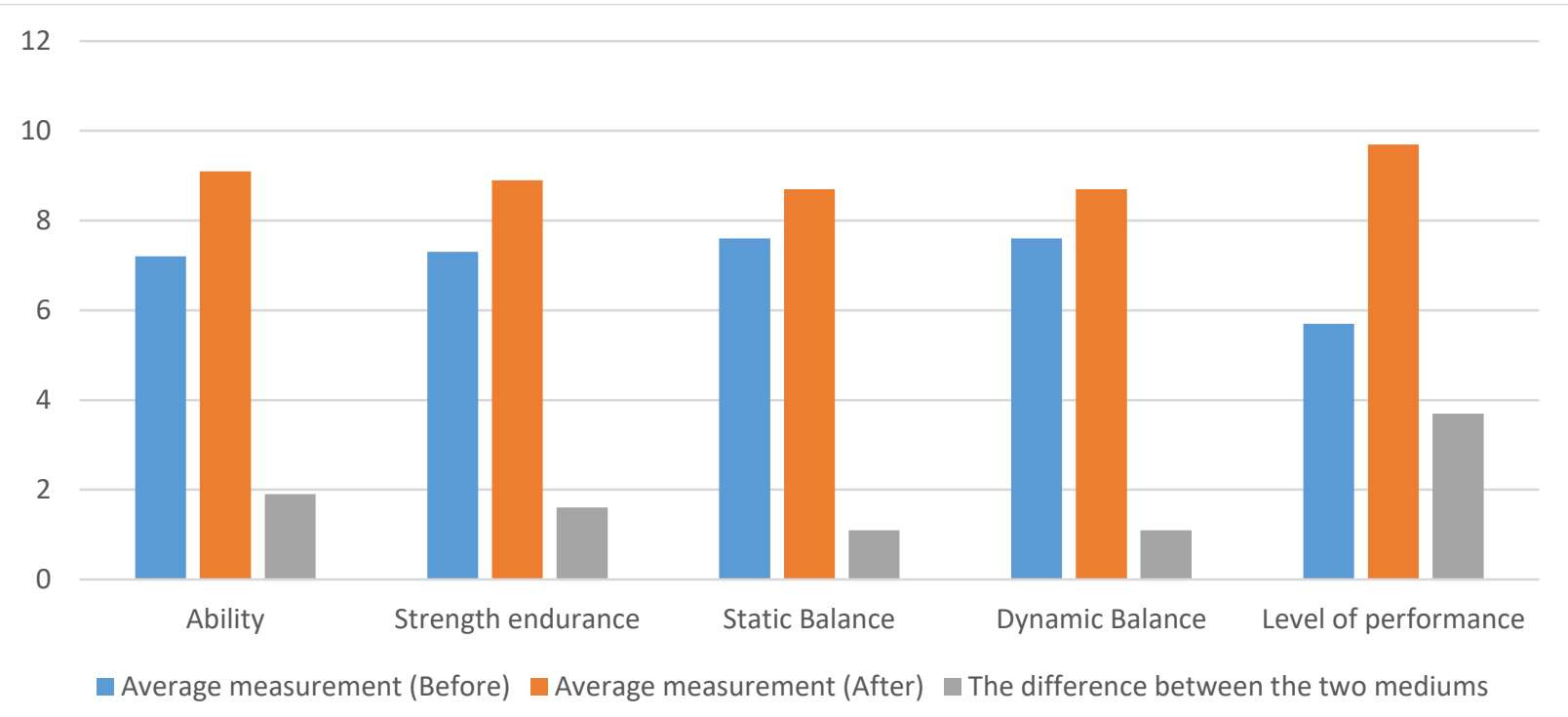

Figure (6) The percentage of improvement between the pre and post measurements in the components of functional strength and the level of performance of the study sample

\section{7/1/2 Display data for kinematic variables}

7/1/2/1 The kinematic variables of the pre and post dimensional measurement of the lower limb in the performance stages: 
Table 7. Average of the lower limb kinematic variables (Before)

\begin{tabular}{|c|c|c|c|c|c|c|c|c|c|c|c|c|c|c|c|c|c|c|c|c|c|}
\hline \multirow{2}{*}{\multicolumn{3}{|c|}{ Variables }} & \multicolumn{3}{|c|}{ Left Thigh } & \multicolumn{4}{|c|}{ Right Thigh } & \multicolumn{3}{|c|}{ Left Leg } & \multicolumn{3}{|c|}{ Right Leg } & \multicolumn{3}{|c|}{ Left Foot } & \multicolumn{3}{|c|}{ Right Foot } \\
\hline & & & \multirow{2}{*}{$\begin{array}{c}1^{\text {st }} \\
\text { Phase } \\
0.12\end{array}$} & \multirow{2}{*}{$\begin{array}{c}\begin{array}{c}2^{\text {nd }} \\
\text { Phase }\end{array} \\
0.40\end{array}$} & \multirow{2}{*}{$\begin{array}{c}3^{\text {rd }} \\
\text { Phase } \\
0.76\end{array}$} & \multirow{2}{*}{$\begin{array}{c}1^{\text {st }} \\
\text { Phase } \\
0.12\end{array}$} & \multirow{2}{*}{$\begin{array}{c}\begin{array}{c}2^{\text {nd }} \\
\text { Phase }\end{array} \\
0.40\end{array}$} & \multicolumn{2}{|c|}{$\begin{array}{c}3^{\text {rd }} \\
\text { Phase } \\
\end{array}$} & \multirow{2}{*}{$\begin{array}{c}1^{\text {st }} \\
\text { Phase } \\
0.12\end{array}$} & \multirow{2}{*}{$\begin{array}{c}2^{\text {nd }} \\
\text { Phase } \\
0.40\end{array}$} & \multirow{2}{*}{$\begin{array}{c}3^{\text {rd }} \\
\text { Phase } \\
0.76\end{array}$} & \multirow{2}{*}{$\begin{array}{c}1^{\text {st }} \\
\text { Phase }\end{array}$} & \multirow{2}{*}{$\begin{array}{c}\begin{array}{c}2^{\text {nd }} \\
\text { Phase }\end{array} \\
0.40\end{array}$} & \multirow{2}{*}{$\begin{array}{c}3^{\text {rd }} \\
\text { Phase } \\
0.76\end{array}$} & \multirow{2}{*}{$\begin{array}{c}1^{\text {st }} \\
\text { Phase }\end{array}$} & \multirow{2}{*}{$\begin{array}{c}\begin{array}{c}2^{\text {nd }} \\
\text { Phase }\end{array} \\
0.40\end{array}$} & \multirow{2}{*}{$\begin{array}{c}3^{\text {rd }} \\
\text { Phase } \\
0.76\end{array}$} & \multirow{2}{*}{$\begin{array}{c}1^{\text {st }} \\
\text { Phase } \\
0.12\end{array}$} & \multirow{2}{*}{$\begin{array}{c}2^{\text {nd }} \\
\text { Phase } \\
0.40\end{array}$} & \multirow{2}{*}{$\begin{array}{c}3^{\text {rd }} \\
\text { Phase } \\
0.76\end{array}$} \\
\hline $\mathrm{Ti}$ & & $\mathrm{t}$ & & & & & & 0.7 & & & & & & & & & & & & & \\
\hline \multirow{9}{*}{ 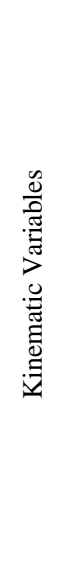 } & \multirow{3}{*}{ 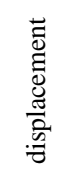 } & Dx & -0.762 & 0.44 & 4.04 & 0.98 & 1.162 & 1.31 & & -5.944 & -9.766 & 6.180 & 7.935 & 9.543 & 9.423 & 0.025 & 1.295 & 1.66 & -0.096 & 3.80 & -5.40 \\
\hline & & Dy & -5.09 & 1.79 & 4.98 & -3.32 & 3.98 & 5.9 & & -3.616 & 0.507 & 3.596 & -4.417 & -0.892 & 2.692 & 0.131 & 2.527 & 1.995 & -0.124 & 2.68 & 2.899 \\
\hline & & Dr & 5.20 & 26.155 & 50.74 & 2.74 & 20.26 & 34.4 & & 8.57 & 26.62 & 41.32 & 9.67 & 24.61 & 38.30 & 0.767 & 8.967 & 26.944 & 0.457 & 7.910 & 25.97 \\
\hline & \multirow{3}{*}{$\begin{array}{l}\frac{2}{0} \\
\frac{0}{0} \\
\frac{0}{3}\end{array}$} & $V x$ & $0.07-$ & 0.077 & 0.056 & 0.065 & 0.016- & 0.0 & & $0.5-$ & 0.15 & 0.01 & 0.478 & $0.04-$ & 0.00 & 0.01 & 0.231 & $0.33-$ & 0.00 & $0.36-$ & 0.329 \\
\hline & & Vy & $0.473-$ & 0.638 & $0.267-$ & $0.30-$ & 0.59 & 0.41 & & $0.311-$ & 0.44 & $0.244-$ & $0.349-$ & 0.468 & $0.26-$ & $0.019-$ & 0.253 & $0.135-$ & $0.037-$ & 0.197 & $0.166-$ \\
\hline & & $\mathrm{Vr}$ & 0.488 & 0.749 & 0.679 & 0.35 & 0.61 & 0.4 & & 0.70 & 0.55 & 0.44 & 0.46 & 0.55 & 0.356 & 0.08 & 0.541 & 0.418 & 0.0671 & 0.482 & 0.50 \\
\hline & \multirow{3}{*}{ 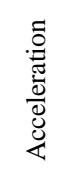 } & Ax & 0.51 & $0.44-$ & 0.91 & 0.21 & 0.30 & 0.1 & & 1.713 & $0.088-$ & 0.56 & $2.30-$ & 0.434 & $0.48-$ & 0.172 & 0.25 & $0.188-$ & 0.63 & $0.189-$ & 0.15 \\
\hline & & Ay & $0.045-$ & 0.198 & 2.90 & 0.65 & $0.94-$ & 0.1 & & 0.488 & $0.254-$ & 0.54 & $0.87-$ & 0.041 & 0.98 & $1.73-$ & $0.22-$ & 0.218 & $0.45-$ & 0.21 & 0.289 \\
\hline & & $\mathrm{Ar}$ & 1.352 & 0.89 & 0.39 & 0.514 & $0.44-$ & 0.18 & & $1.07-$ & $0.22-$ & 0.89 & $1.74-$ & 0.172 & 0.845 & $1.214-$ & 0.219 & $0.35-$ & $0.264-$ & 0.231 & $0.364-$ \\
\hline & & & & & & & & & $a b l$ & e $8 . \mathrm{Boc}$ & $y$ angl & es under & study $(b$ & efore) & & & & & & & \\
\hline & & & & & & & & & & Phase Ay & erage & $2^{\text {nd }}$ Phase & Average & $3^{\text {rd }} \quad \mathrm{Ph}$ & e Average & & & & & & \\
\hline & & & & & & & $\mathrm{T}$ & & & 0.12 & & 0.4 & & & 76 & & & & & & \\
\hline & & & & & & & Left K & & & 164 & & 144 & & & 77 & & & & & & \\
\hline & & & & & & & Right $\mathrm{F}$ & & & 165 & & 131 & & & 67 & & & & & & \\
\hline & & & & & & & Left A & & & 81 & & 69 & & & 45 & & & & & & \\
\hline & & & & & & & Right $A$ & kle & & 91 & & 49 & & & 52 & & & & & & \\
\hline
\end{tabular}




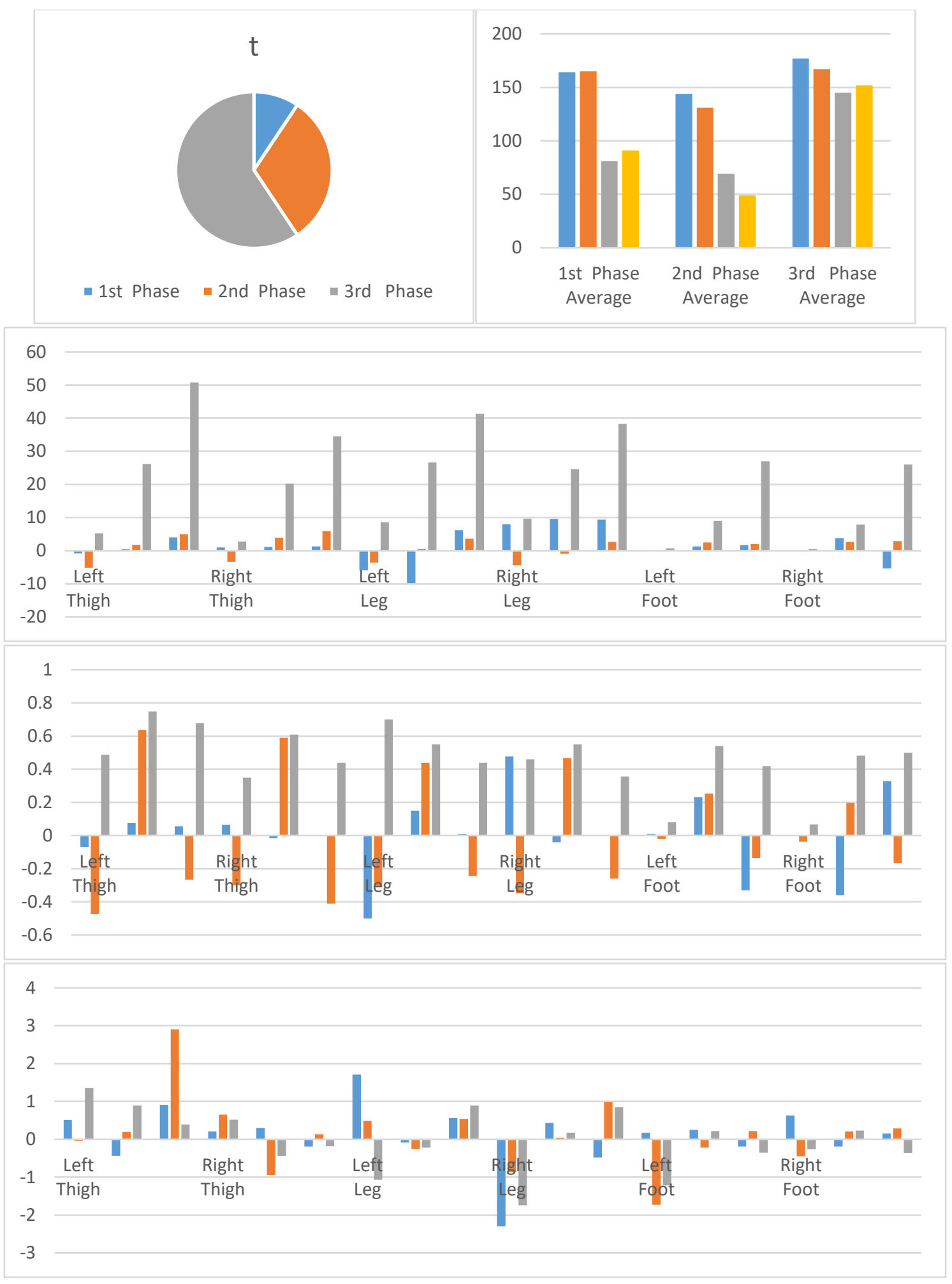



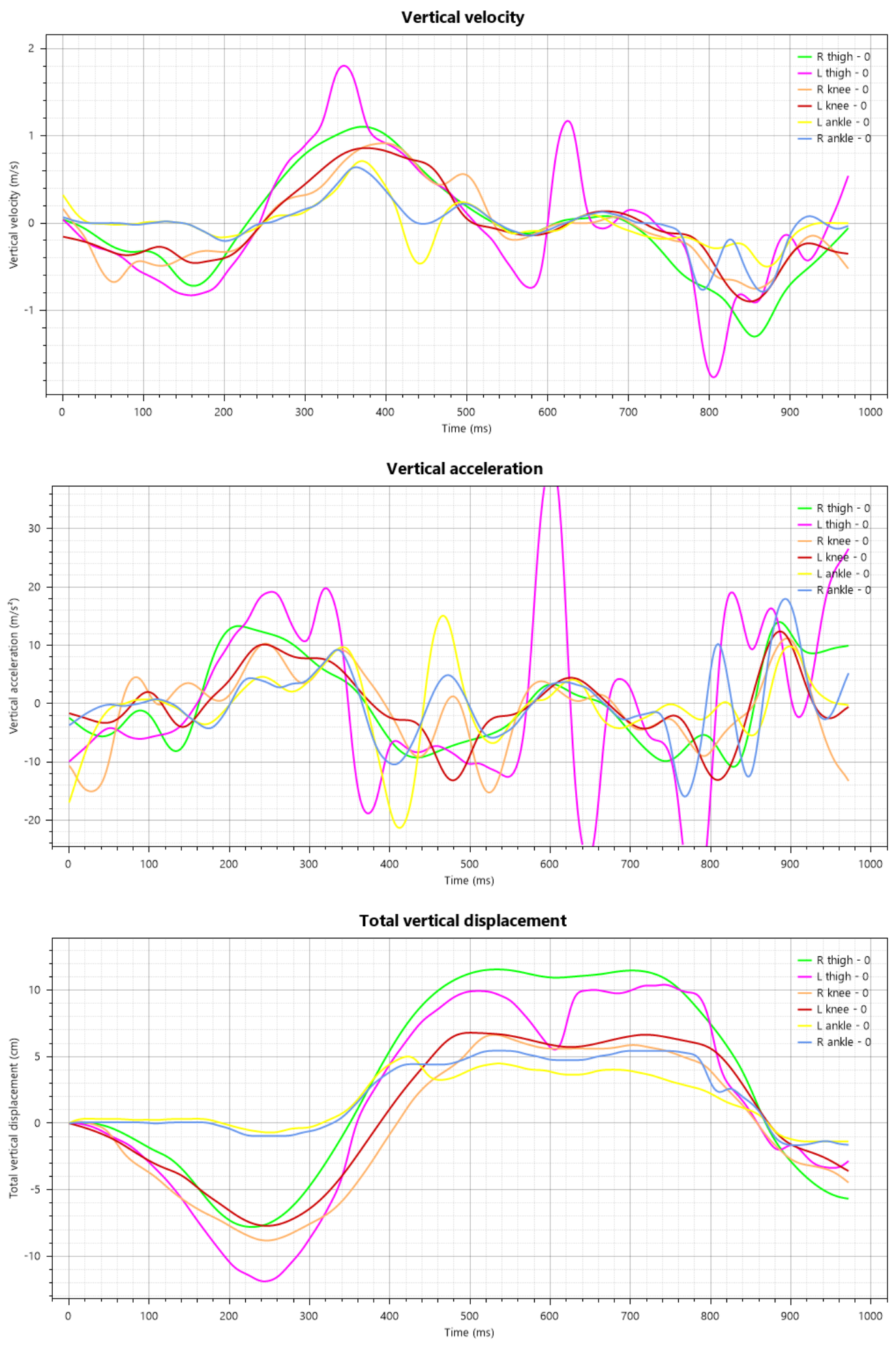

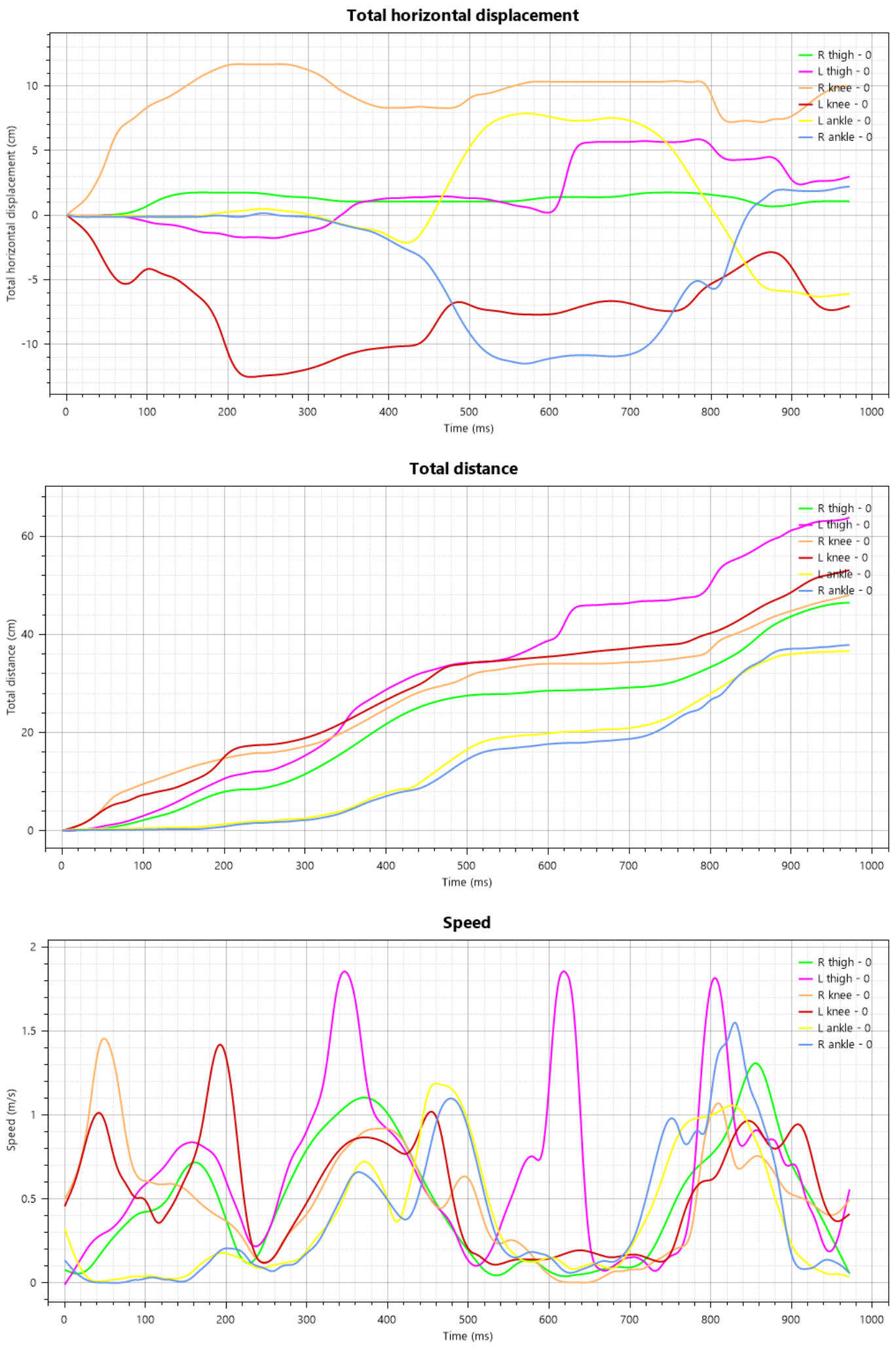

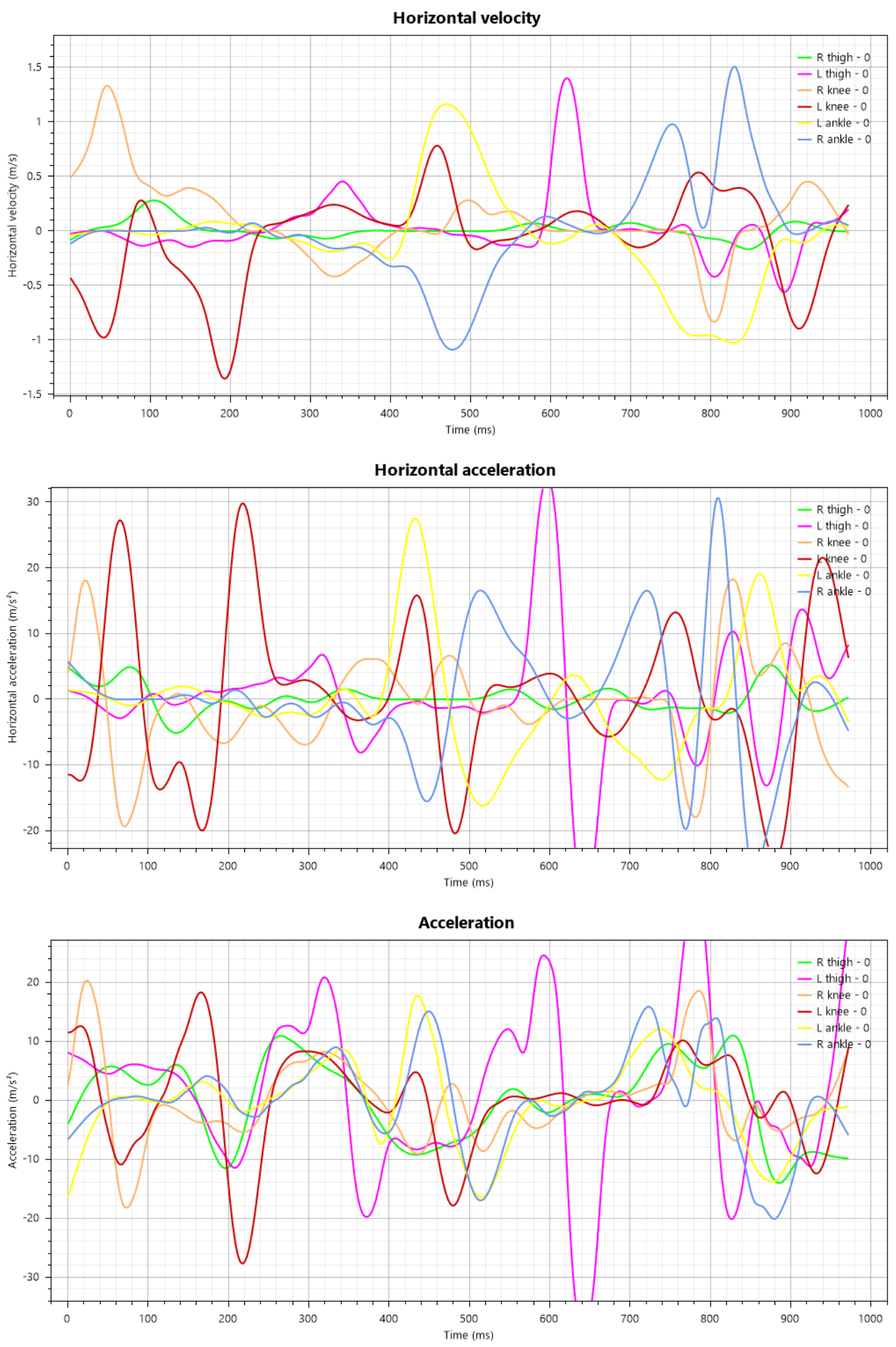

Figure (7) Kinematic variables under study (Before) 
Table 9. Average of the lower limb kinematic variables (After)

\begin{tabular}{|c|c|c|c|c|c|c|c|c|c|c|c|c|c|c|c|c|c|c|c|c|}
\hline \multirow{2}{*}{\multicolumn{3}{|c|}{ Variables }} & \multicolumn{3}{|c|}{ Left Thigh } & \multicolumn{3}{|c|}{ Right Thigh } & \multicolumn{3}{|c|}{ Left Leg } & \multicolumn{3}{|c|}{ Right Leg } & \multicolumn{3}{|c|}{ Left Foot } & \multicolumn{3}{|c|}{ Right Foot } \\
\hline & & & \multirow{2}{*}{$\begin{array}{c}1^{\text {st }} \\
\text { Phase } \\
0.164\end{array}$} & \multirow{2}{*}{$\begin{array}{c}2^{\text {nd }} \\
\text { Phase } \\
0.479\end{array}$} & \multirow{2}{*}{$\begin{array}{c}3^{\text {rd }} \\
\text { Phase } \\
0.854\end{array}$} & \multirow{2}{*}{$\begin{array}{c}1^{\text {st }} \\
\text { Phase }\end{array}$} & \multirow{2}{*}{$\begin{array}{c}2^{\text {nd }} \\
\text { Phase } \\
0.479\end{array}$} & \multirow{2}{*}{$\begin{array}{c}3^{\text {rd }} \\
\text { Phase } \\
0.854\end{array}$} & \multirow{2}{*}{$\begin{array}{c}\begin{array}{c}1^{\text {st }} \\
\text { Phase }\end{array} \\
0.164\end{array}$} & \multirow{2}{*}{$\begin{array}{c}\begin{array}{c}2^{\text {nd }} \\
\text { Phase }\end{array} \\
0.479\end{array}$} & \multirow{2}{*}{$\begin{array}{c}\begin{array}{c}3^{\text {rd }} \\
\text { Phase }\end{array} \\
0.854\end{array}$} & \multirow{2}{*}{$\begin{array}{c}\begin{array}{c}1^{\text {st }} \\
\text { Phase }\end{array} \\
0.164\end{array}$} & \multirow{2}{*}{$\begin{array}{c}\begin{array}{c}2^{\text {nd }} \\
\text { Phase }\end{array} \\
0.479\end{array}$} & \multirow{2}{*}{$\begin{array}{c}3^{\text {rd }} \\
\text { Phase } \\
0.854\end{array}$} & \multirow{2}{*}{$\begin{array}{c}1^{\text {st }} \\
\text { Phase } \\
0.164\end{array}$} & \multirow{2}{*}{$\begin{array}{c}\begin{array}{c}2^{\text {nd }} \\
\text { Phase }\end{array} \\
0.479\end{array}$} & \multirow{2}{*}{$\begin{array}{c}\begin{array}{c}3^{\text {rd }} \\
\text { Phase }\end{array} \\
0.854\end{array}$} & \multirow{2}{*}{$\begin{array}{c}1^{\text {st }} \\
\text { Phase }\end{array}$} & \multirow{2}{*}{$\begin{array}{c}\begin{array}{c}2^{\text {nd }} \\
\text { Phase }\end{array} \\
0.479\end{array}$} & \multirow{2}{*}{$\begin{array}{c}\begin{array}{c}3^{\text {rd }} \\
\text { Phase }\end{array} \\
0.854\end{array}$} \\
\hline & & $\mathrm{t}$ & & & & & & & & & & & & & & & & & & \\
\hline \multirow{9}{*}{ 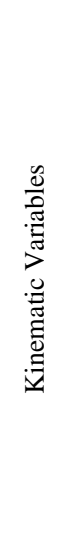 } & \multirow{3}{*}{ 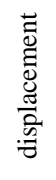 } & Dx & 0.01 & 1.40 & 0.93 & 1.84 & 2.14 & 1.28 & 8.34 & 9.56 & 9.61 & -786 & -8.86 & -6.18 & 0.01 & 1.78 & 4.31 & 0.35 & -2.46 & -2.76 \\
\hline & & Dy & -6.77 & -1.60 & -1.45 & -5.84 & -4.29 & -0.184 & -3.92 & -0.01 & 2.88 & -4.17 & 1.02 & 3.62 & -0.399 & 2.81 & 6.56 & -0.39 & 2.50 & 3.21 \\
\hline & & Dr & 7.07 & 33.1 & 51.07 & 6.31 & 28.299 & 49.09 & 9.44 & 30.31 & 49.02 & 9.07 & 31.08 & 47.81 & 0.76 & 8.19 & 28.36 & 1.11 & 9.43 & 61.47 \\
\hline & \multirow{3}{*}{$\begin{array}{l}\frac{3}{0} \\
\frac{0}{0} \\
\frac{1}{2}\end{array}$} & Vx & -0.01 & 0.06 & -0.024 & 0.13 & -0.13 & 0.04 & 0.488 & -0.29 & 0.14 & -0.45 & 0.29 & 0.00 & 0.00 & 0.34 & 0.26 & 0.01 & -0.26 & 0.22 \\
\hline & & Vy & -0.51 & 0.76 & -0.28 & -0.45 & 0.66 & -0.33 & -0.28 & 0.616 & -0.313 & -0.30 & 0.66 & -0.358 & -0.04 & 0.30 & -0.19 & 0.04 & 0.23 & -0.12 \\
\hline & & $\mathrm{Vr}$ & 0.55 & 0.84 & 0.55 & 0.49 & 0.88 & 0.45 & 0.59 & 0.78 & 0.48 & 0.59 & 0.77 & 0.412 & 0.06 & 0.61 & 0.44 & 0.08 & 0.68 & 0.49 \\
\hline & \multirow{3}{*}{ 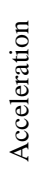 } & $A x$ & 0.377 & -0.52 & 0.36 & -0.13 & 0.08 & 1.16 & -0.58 & 1.46 & -1.60 & 0.866 & -0.68 & 0.725 & -0.05 & 1.376 & -0.62 & -0.26 & 0.22 & -0.292 \\
\hline & & Ay & 1.009 & -2.44 & 2.88 & 0.818 & -0.64 & -0.269 & 0.245 & -0.79 & 0.77 & 0.328 & -0.788 & -0.313 & -0.022 & -0.271 & 0.215 & 0.0257 & -0.50 & 1.07 \\
\hline & & $\mathrm{Ar}$ & 1.582 & -0.83 & 1.55 & 0.803 & 0.439 & 0.304 & 0.287 & 0.928 & 0.547 & 0.418 & -0.283 & 0.350 & 0.175 & 1.488 & -0.88 & -0.034 & 1.42 & -0.374 \\
\hline
\end{tabular}

Table 10. Body angles under study (After)

\begin{tabular}{c|c|c|c}
\hline \hline & $1^{\text {st }}$ Phase Average & $2^{\text {nd }}$ Phase Average & $3^{\text {rd }}$ Phase Average \\
\hline \hline $\mathrm{T}$ & 0.16 & 0.47 & 0.85 \\
\hline Left Knee & 171 & 125 & 184 \\
\hline Right Knee & 161 & 116 & 178 \\
\hline Left Ankle & 63 & 84 & 168 \\
\hline Right Ankle & 71 & 82 & 171 \\
\hline \hline
\end{tabular}



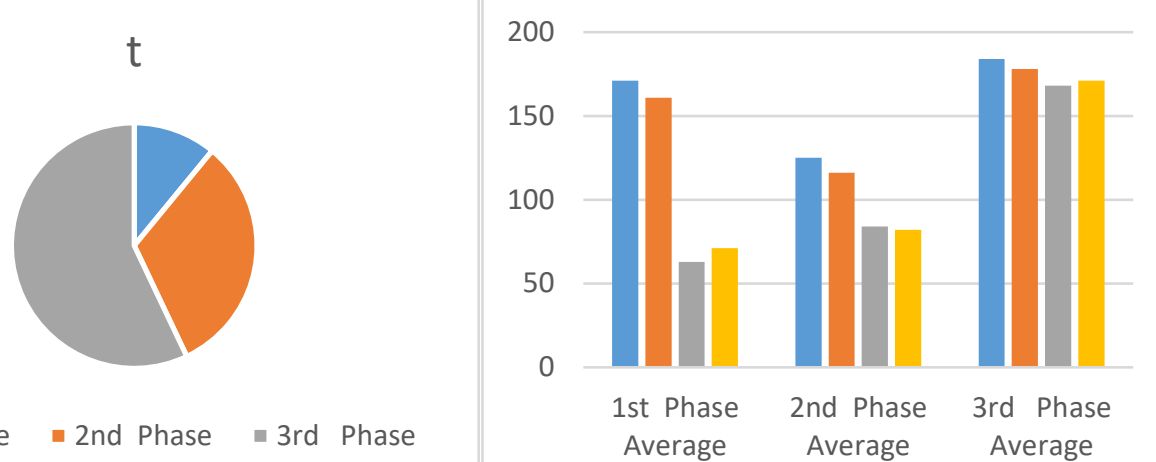

- 1st Phase - 2nd Phase " 3rd Phase

Average Average Average

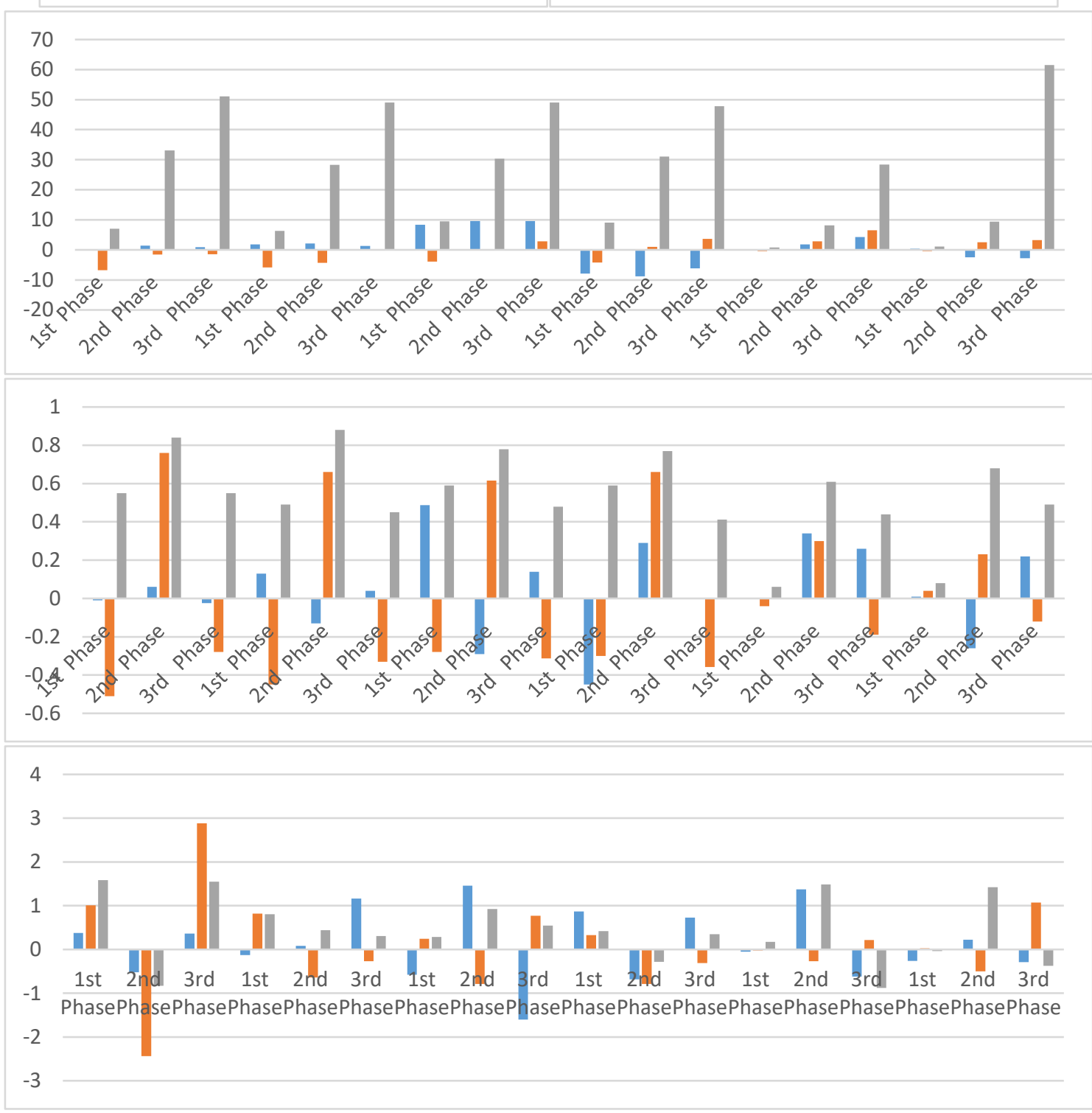



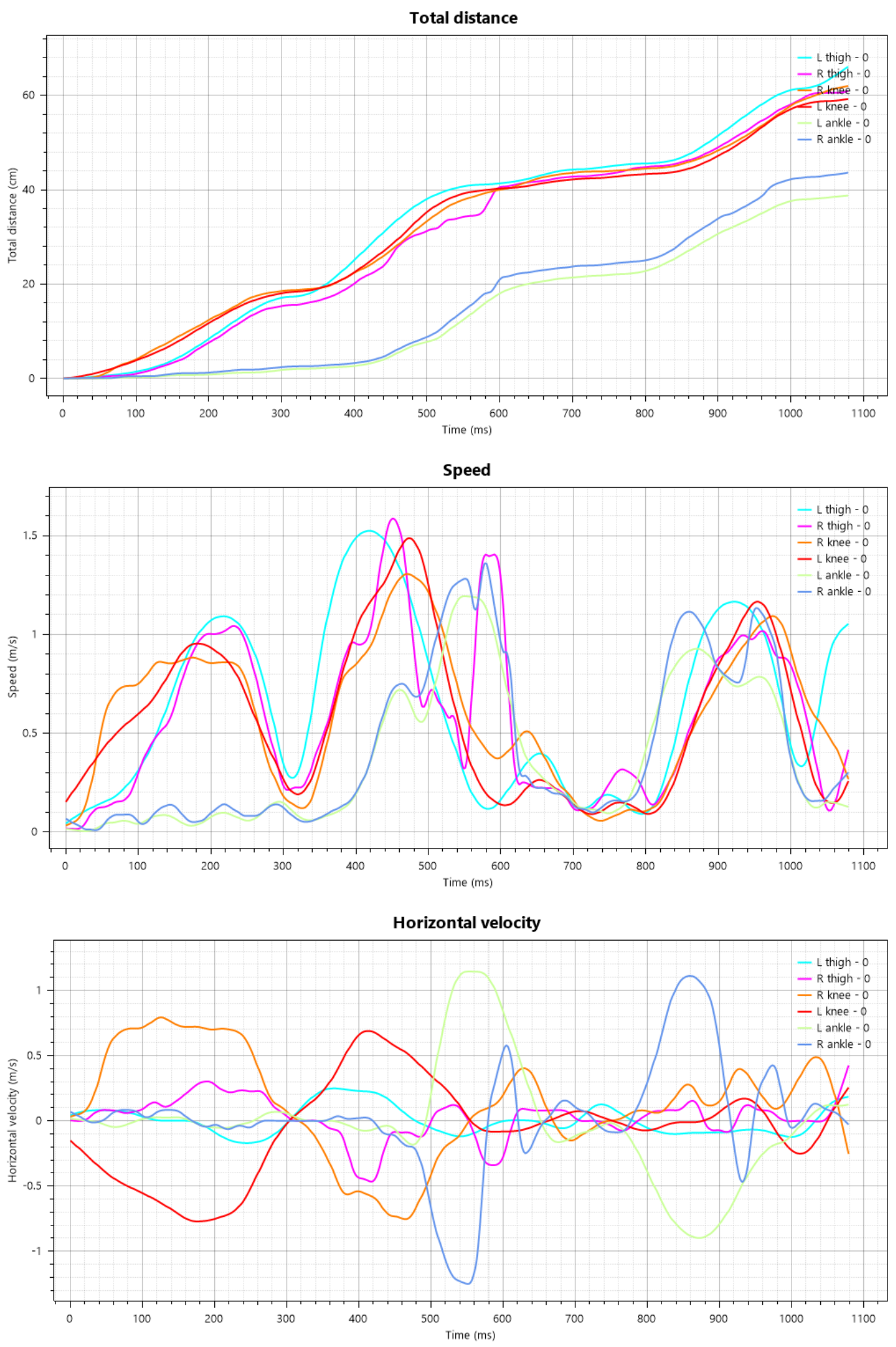

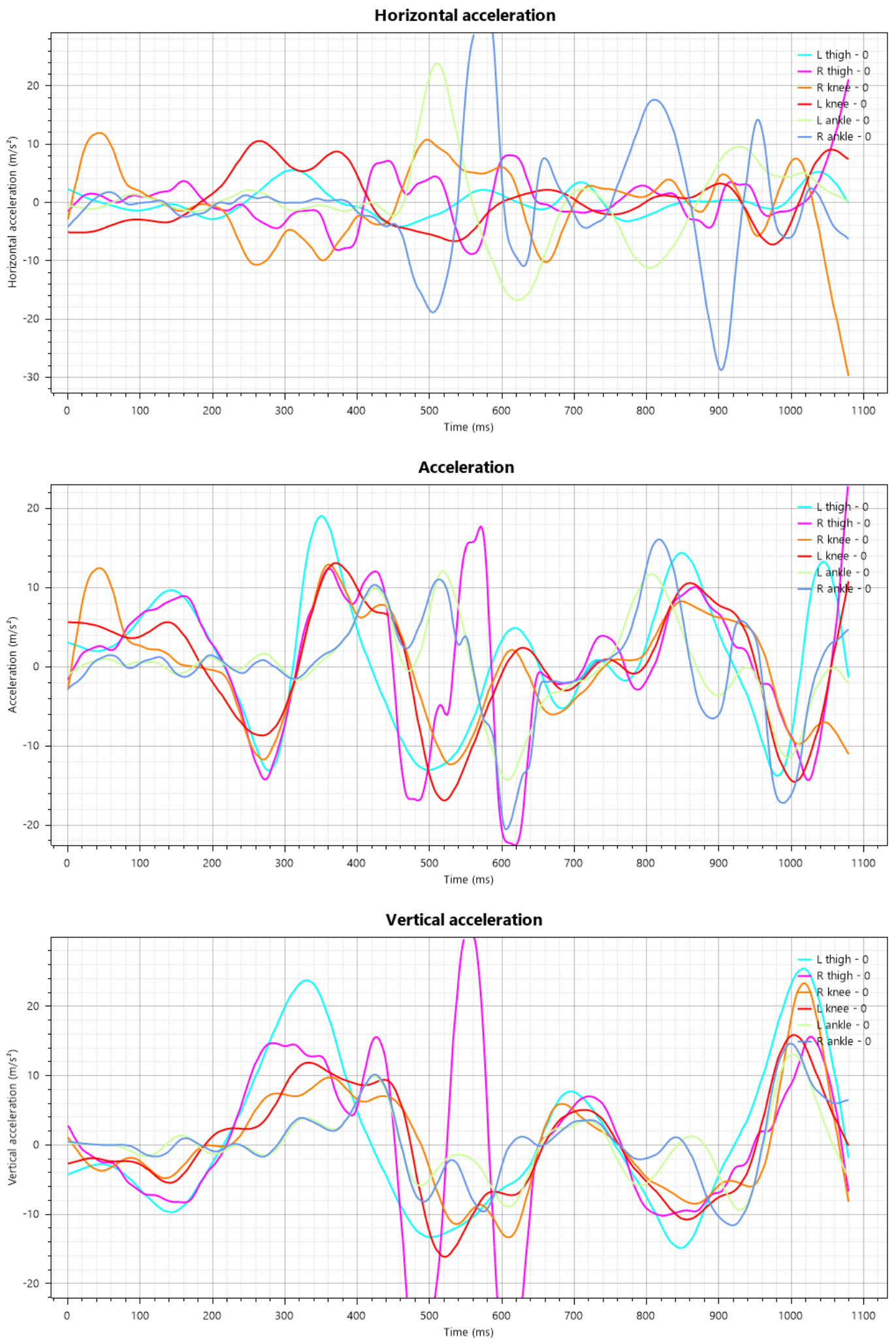

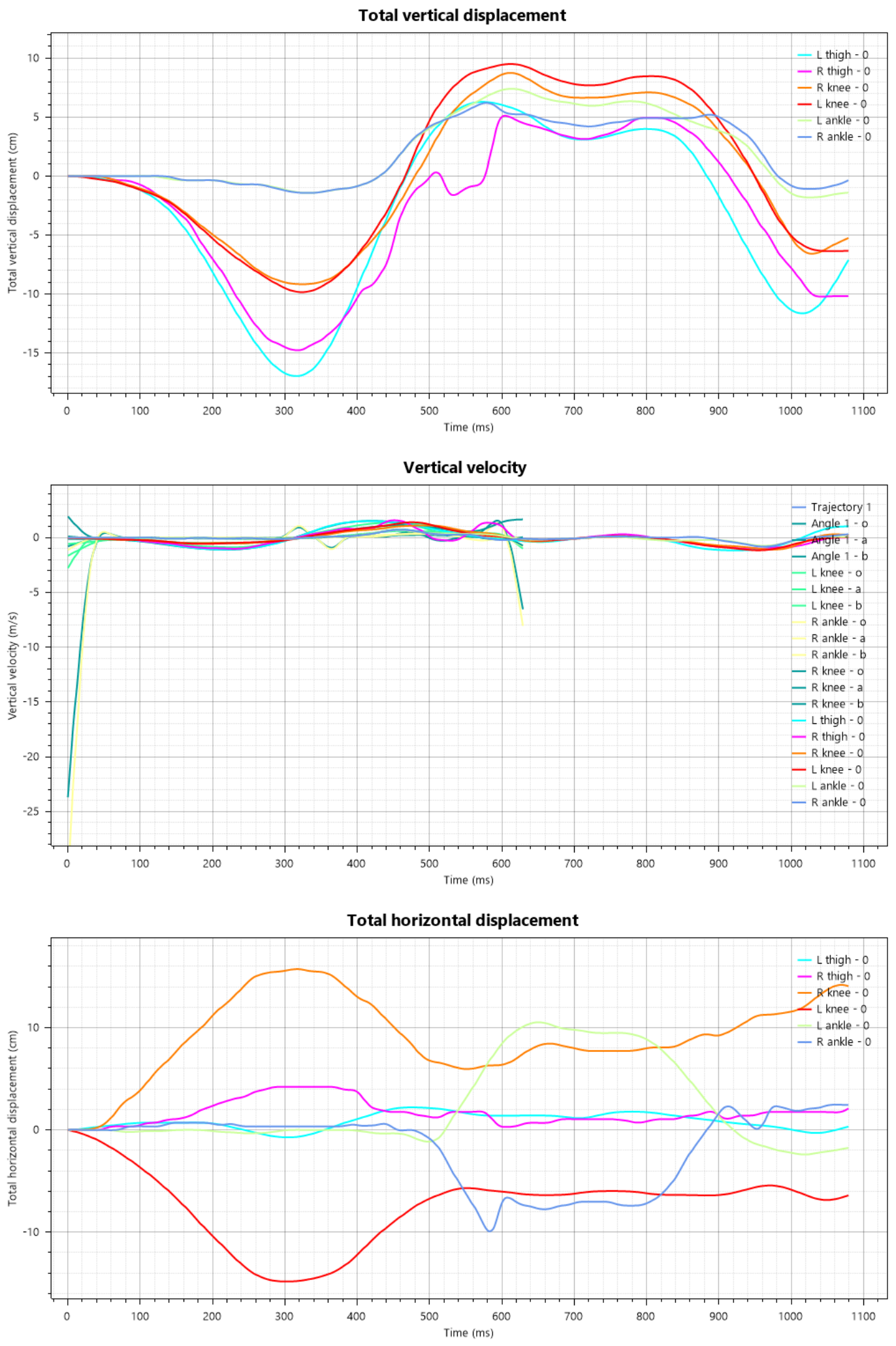

Figure (8) Kinematic variables under study (After) 


\section{7/2 Discussion of the results:}

\section{7/2/1 Discussion of the results of the first Question:}

Which states that "there are statistically significant differences between the pre and post measurements in each of the components of job strength and the level of skill performance understudy."

It is clear from Table (4), (5), (6) that there are statistically significant differences between the pre and post measurements in each of the components of functional strength and the level of skill performance under discussion, and the researchers attribute this improvement to the exercises of codified functional strength based on scientific foundations that depend Primarily on the kinematic analysis of the skill in question, through which its strengths and weaknesses were identified and work on improving technical characteristics in all its stages.

Also, the kinematic analysis of performance is the objective means of evaluating skill performance without bias and is used in many activities, especially those that are fast, such as jumping movements, as it depends on a set of variables such as (displacement, speed, and strength).

Jumping is considered one of the most difficult basic skills in ballet, which requires special specifications, preparations, abilities, and components for students to control the muscles of the two men, such as the muscular strength of the two men (the force characterized by speed), the bearing of strength for the two men, and the balance of its fixed and dynamic types.

Mohammed Hassanein (2001) (7) believes that the muscular ability is one of the main components in practicing many sports activities as it reflects the student's strength, speed, and energy in integrating the maximum force to get it out in the fastest time, as this is clearly shown in the ability to combine strength and speed while performing the jump skill in question.

Yasmine El-Naggar and Susan Tantawi (2004) (11) indicate that the student needs the muscular ability to overcome resistance with the highest muscle contractility speed when performing the ascension for any dart, as it primarily depends on the speed of the muscle contraction of the foot muscles, so the student can improve by using A small number of muscles but at high speed.

Laila Farahat (2005) 10 confirms that the muscular ability is one of the factors that affect performance and a key factor in the success of the vaulting movements.

Dillman, L (2006) (17) states that jumping is an essential part of ballet and is a movement that requires a smooth flow of the performance and a link between muscle contractions, relaxation, and strength marked with speed.

Haas, J. G. (2018) (22) adds that ballet involves a high degree of skill, which requires a range of functional strength components, including muscle ability.

As agreed with Juan, Escobar-Alvarez \& Fuentes, Juan \& Conceicao, Filipe \& JimenezReyes, Pedro. (2019) (24) that to perform the technical difficulties associated with documenting in ballet, training programs must pay attention to raising the level of muscle ability.

The researchers believe that bearing strength for the muscles of the two men is an important and important functional strength component of the Le Petit Echappe' in the ballet as it is the ability to continue to force the strength in front of resistors for a long time.

Issam Abdel-Khalek (2003) (6) notes that the student's efficiency in overcoming fatigue during the continuous effort is the presence of relatively high resistors, as it includes with the muscular ability with endurance, so it expresses the student's competence to work for a long time under conditions of effective influence resistors And it is important in sports activities that need to link endurance and strength in which the student overcomes resistance for a long time. 
The researchers believe that the balance is one of the important and fundamental functional strength components that depend greatly on many sporting activities in general and ballet in particular, as it is the beginning of movements and the end of other movements, as it is done in most situations and trends of stability and movement.

Muhammad Hassanein (2001) (7) states that balance is the ability to maintain a specific position of the body during steadiness or movement, and balance with its constant and dynamic types has a general ability that highlights their importance in life in general and in the field of physical and athletic education in particular as it is an important component in the performance of basic motor skills such as walking and standing Jumping

It is also key in most sporting activities, especially those that require standing or moving over a narrow space, such as gymnastics, ballet, and exercise, and it is associated with many physical characteristics such as strength.

Samia Al-Hajrasi (2004) (4) indicates that to achieve the optimum performance for the various motor skills, the student must maintain her balance when performing.

Laila Farahat (2005) 10 confirms that balance plays an important role in achieving high results in jumping skills as it is a basic requirement, especially during the landing stage after jumping.

It also agrees with Shanok, Nathaniel \& Meltzer, Kelsey \& Frank, Colin \& Lugo, Victoria \& Jones, Nancy. (2020) (36) in that muscle strength and balance are among the main elements of job training, as the balance increases the speed of mastering the complex technical aspects of the skill and helps to perform it easily and easily as it helps the student to reach the highest possible level.

The researchers believe that the skill performance is closely related to the components of the functional force as Le Mastit Echappe's mastery of skill depends on the extent of developing the components of the functional strength that it requires, which can be developed and improved through a set of standardized exercises for the functional strength as it works on different muscle groups simultaneously. To perform a variety of different functions.

It also agrees with Richards, Jim (2019) (32) that job training means performing work against different resistances in a specific way and thus can benefit from the force produced from them in the implementation of the requirements of daily life, and movements related to sports activity practiced in particular, and each movement has a goal and the main concept Crucial to job training is transfer or transfer of strength to achieve the goal of the movement, as the transfer of training can give coaches the ability to design successful and functional training programs that can be applied and utilized in the sports field.

\section{7/2/2 Discussion of the results of the second Question:}

Which states that "there are differences between the pre and post measurements in each of the kinematical parameters of skill performance understudy"

It is clear from two tables (8) and (10) that there are differences between the pre and post measurements of the study group in the time variable during the three phases of performance, where the average total skill time in the pre-measurement was $(1.28 \mathrm{w})$, while in the postmeasurement it was about (1.497) W), and the researchers attribute this to the fact that the research sample realizes that the shortening of the skill time does not occupy the greatest interest in performance, but the frequency of the skill, the form of performance, and the flow of movement are the most important criterion in the skill's performance. 
The researchers also attribute this to the weakness of the muscles of the two men responsible for performing the skill that led to the absence of moments of stability on the comb, unlike the dimensional measurement, which is evident from the increase in the skill time and the ability of the sample to rest on the combs for a longer period.

Despite the increase in the speed of performance in telemetry, as shown in two tables (7) and (9), the time in telemetry has become greater than in pre-measurement.

In agreement with Juan, Escobar-Alvarez \& Reyes, Pedro \& Pérez-Sousa, Miguel A. \& Conceicao, Filipe \& Fuentes, Juan (2020) (25), and Clippinger, K. S. (2016) (13).

It also turns out that the third stage of pre- and post-performance is the most time consuming of the total time to perform the skill as it took in the pre-measurement between $59.4 \%$ and in the post-measurement $57.4 \%$ of the total time to perform the skill, and the researchers attribute this to the fact that the third stage includes bending the knees to reach the situation The fifth, with the body's center of gravity moving behind and the performance of this movement shared by a large number of leg muscles, the posterior muscles, which are less powerful and smaller than the front muscles. The researchers attribute the reduction in the performance time in the dimensional measurement to the increase in the strength of the posterior muscles as a result of the proposed training program using exercises to improve functional strength.

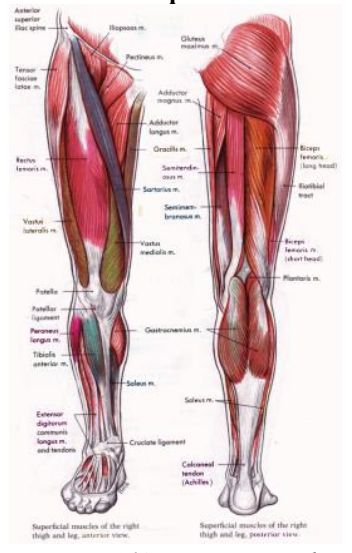

Figure (1) Legs muscles

The third stage is also the beginning of a new movement and skill, so it is important to reduce the time of this stage to facilitate its integration with a new skill.

Consistent with Clippinger, K. S. (2016) (13), Gretchen D. Oliver and Ro di Brezzo (2009) (20).

As evidenced by two tables (8) and (10) above the knee and wrist angles above the first and second measurements, the researchers attribute this to the fact that the job training used has led to the development and development of the functional strength elements under study.

Where it is clear that the small angle of the wrist of the feet in the first stage, which indicates the ability of the research sample to bend the legs to a large degree, which indicates an increase in the ability to bear the resulting strength to rest in that position.

The results of the tables (8) and (10) also confirm the increase in the widening angle of the knees and the carpal feet, which indicates an increase in the flexibility of the joint as it indicates an increase in the ability of the player to reach a full standing position without the presence of flexion in the knees This indicates that the proposed functional exercises worked to increase The muscular skin of the two legs, which helped withstand the player, fully flatten the legs, tighten the muscles, and straighten the joints of the man completely and smoothly. 
According to the study of Doaa Muhammad (2009) (2), and Heba Muhammad (2004) (9), the arrangement of muscles according to the measurement of the electrical activity of the two men was as follows:

Table 11. Arrange the muscles according to the measurement of the electrical activity of the two legs

\begin{tabular}{|c|c|c|c|}
\hline & \multicolumn{2}{|l|}{ Muscle } & $\%$ \\
\hline 1 & Right Rectus Femoris & & $\% 14$ \\
\hline 2 & Left Rectus Femoris & & $\% 23$ \\
\hline 3 & Right Vactus Medialis & & $\% 11$ \\
\hline 4 & Left Vactus Medialis & $=\frac{1}{2}$ & $\% 9$ \\
\hline 5 & Right Sartorius & & $\% 14$ \\
\hline 6 & Left Sartorius & & $\% 13$ \\
\hline 7 & Right Biceps Femroris & 8 & $\% 9$ \\
\hline 8 & Left Biceps Femroris & H. & $\% 9$ \\
\hline
\end{tabular}

As shown in tables (7) and (9), the increased speed achieved for all parts of the two men understudy at all stages in the dimensional measurement, and the researchers attribute this to the increase in the speed obtained as a result of functional and special training of the explosive force component, which was trained on the strength of performance in The lowest possible time, which increased the speed of the muscle response and activated the nerve signals in the brain, which contributed to the increase in speed, which is consistent with Kumar, S. (1999) (26), Payton, CJ, \& Bartlett, RM (2018) (31).

\section{8/0 Conclusions}

Within the limits of the study objectives, hypotheses, data used and the results presented, the researcher concludes the following:

- Determining the kinematical parameters for performing the Le Petit Echappe' skill in ballet.

- Improving the components of the job force to perform the "Le Petit Echappe'" skill in ballet, as a result of applying the suggested job strength training to the study sample.

- The level of performance of Le Petit Echappe' skill in the ballet during its three phases, as a result of applying the proposed job strength training to the study sample.

- The proposed strength training exercises affected improving the performance of the Le Petit Echappe' skill in the corners of the two legs and significantly increasing the men's flexibility.

- Of the critical biodynamic variables in Le Petit Echappe' in ballet with a jump (total time - second stage performance time - knee angle - vertical velocity in the third stage).

\section{9/0 Recommendations:}

In light of the results of the study results, the researcher recommends the following:

- Studying the components of special functional strength in the rest of the feet 'movements and designing functional strength training to develop them to improve the performance of these skills. I think you need paraphrasing, Doctor

- Dependence during the ballet training process "Le Petit Echappe' in the ballet on the chemical parameters derived from the study. 
- Putting the components of the functional force of the impulsive skill, Le Petit Echappe', in the ballet of interest during the skill training.

- Depending on the kinematic characteristics extracted from the study in constructing various training programs to improve Le Petit Echappe' in ballet.

- Attention in the second stage of the performance of the le Petit Echappe' skill in ballet, by holding on to the y-axis, as it increases the balance.

- Attention, during training on the "Le Petit Echappe'" skill in ballet, in the second stage, provided that the feet touch the ground in the least possible time and the least space possible to increase the beauty of movement.

- Attempting to merge the first and second phases during the ballet training process, Le Petit Echappe', in the ballet.

- Taking into consideration the working muscles during the Le Petit Echappe' skill training session in the ballet.

- Depending on the components of the job force in building and designing the various training programs in the ballet.

\section{0/0 References:}

1- Ahmed Hassan Gomaa: (2005), The Movement in Ballet Art, The Egyptian General Book Organization, Cairo.

2- Dua'a Mohamed Abdel-Moneim: (2009), "The effectiveness of using specific exercises on technical characteristics and the level of performance of the skill Pas Echappe in ballet" unpublished doctoral dissertation, Faculty of Physical Education for Girls, Zagazig University.

3- Zain Nassar: (2008), World of Music, The Egyptian General Book Authority, 2nd edition, Cairo.

4- Samia Ahmad Al-Hajrasi: (2004), an introduction to rhythmic exercises and rhythmic gymnastics scientific and artistic concepts, library, and press of tomorrow, Cairo.

5- Safia Ahmed Mohy El-Din, Samia Rabih Mohamed: (2012) ballet and modern dance, a book for students of the Faculty of Physical Education in the island, 2nd floor, Cairo.

6- Issam Abdel-Khalek: (2003), Athletic Training Theories - Applications, 11th Edition, University Books House, Alexandria.

7- Mohamed Sobhi Hassanein: (2001), measurement and evaluation in physical education and sports, part 1, 1st edition, the book center for publishing, Cairo.

8- Hani Abdulaziz Ibrahim: (2018), "The effect of the use of job-strength training on some physical and biodynamic capabilities. Performing the skill of bouncing in the blade rivals", Assiut Journal of Physical Education Science and Arts, Assiut University.

9- Heba Mohamed Saeed: (2004), "The effectiveness of complementary job training on improving the special physical traits and stages of motor performance of some motor skills in motor exercises" unpublished doctoral dissertation, Faculty of Physical Education for Girls, Zagazig University.

10- Laila Al-Sayed Farhat: (2005), Measurement and Examination in Physical Education, The Book Center for Publishing, Cairo. 
11- Yasmine El-Naggar, Susan Tantawi: (2004), foundations of rhythmic gymnastics training, part 1, Faculty of Physical Education for Girls, Alexandria University.

12- Christine Cunningham (2000): The Importance of Functional Strength Training, Personal Fitness Professional magazine, American Council on Exercise publication, April

13- Clippinger, K. S. (2016). Dance anatomy and kinesiology. Champaign, IL: Human Kinetics.

14- D, Gordon E, Robertson, Gary Kamen, Graham E, Caldwell, Joseph Hamil, Saunders- N, Whittlesey: (2004): Research Methods in Biomechanics, Human Kinetics publisher; Champaign

15- Da Silva-Grigoletto, Marzo \& Resende-Neto, Antônio \& Teixeira, Cauê. (2020). Functional training: a conceptual update. Revista Brasileira de Cineantropometria e Desempenho Humano. 22. 10.1590/19800037.2020v22e72646.

16- Dave, S.(2003): Functional Training Pyramids, New Truer High School, Kinetic Wellness Department, USA.

17- Dillman, L. (2006). Ballet. Chicago, IL: Heinemann Library.

18- Fabio comana (2004): function training for sports, Human Kinetics: Champaign IL, England

19- Gehan Elsawy (2010). Effect of Functional Strength Training on Certain Physical. Variables and Kick of Twimeo Chagi among Young Taekwondo Players. World Journal of Sport Sciences, Volume 4 Number 4

20- Gretchen D. Oliver and Ro di Brezzo (2009). Functional balance training in collegiate women athletes, Journal of Strength and Conditioning Research, 23(7)/2124-2129

21- Grossman, G., \& Phelps, T. (2015). Dance science: Anatomy, movement analysis, and conditioning. Hightstown, NJ: Princeton Book Company.

22- Haas, J. G. (2018). Dance anatomy. Champaign: Human Kinetics.

23- Homans, J. (2011). Apollos angels: A history of ballet. London: Granta.

24- Juan, Escobar-Alvarez \& Fuentes, Juan \& Conceicao, Filipe \& Jimenez-Reyes, Pedro. (2019). Individualized Training Based on Force-Velocity Profiling During Jumping in Ballet Dancers. International journal of sports physiology and performance. 1-7. 10.1123/ijspp.2019-0492.

25- Juan, Escobar-Alvarez \& Reyes, Pedro \& Pérez-Sousa, Miguel A. \& Conceicao, Filipe \& Fuentes, Juan. (2020). Analysis of the Force-Velocity Profile in Female Ballet Dancers. Journal of dance medicine \& science: official publication of the International Association for Dance Medicine \& Science. 24. 10.12678/1089-313X.24.2.59.

26- Kumar, S. (1999). Biomechanics in ergonomics. Taylor \& Francis.

27- Laws, K., \& Sugano, A. (2008). Physics and the art of dance: Understanding movement. New York: Oxford University Press.

28- Öktem, Hale \& Pelin, Can \& Kürkçüoğlu, Ayla \& İzci, Merve \& Şençelikel, Tuğçe. (2019). Evaluation of posture and flexibility in ballet dancers. Anatomy. 13. 10.2399/ana.19.058.

29- Osama Abdel Rahman Ali (2008): Effect of functional strength training on bone mineral density and performance level of fleche and lunge for youth fencers, pre-Olympic congress, china. 
30- Pakes,

Ann

(2020)

Action-Ballet

and 10.1093/oso/9780199988211.003.0003.

31- Payton, C. J., \& Bartlett, R. M. (2018). Biomechanical Evaluation of Movement in Sport and Exercise: The British Association of Sport and Exercise Sciences Guidelines.

32- Richards, Jim. (2019). Functional Training, Translating Training Effects into Functional Movement.

33- Ron, J.(2003): Function Training 1: Introduction, Reebo Santana, Jose Carlos Univ., USA.

34- Rozikovich, Soliyev. (2020). Functional Training Level of Runners Student-athletes Sprinters. International Journal of Psychosocial Rehabilitation. 24. 2028-2033. 10.37200/IJPR/V24I5/PR201878.

35- Scott Gaines (2003): Benefits and Limitations of Functional Exercise, Vertex Fitness, NESTA , USA

36- Shanok, Nathaniel \& Meltzer, Kelsey \& Frank, Colin \& Lugo, Victoria \& Jones, Nancy. (2020). The Efficacy of Executive Function Training for Reducing Childhood Anxiety. 10.13140/RG.2.2.11112.49926.

37- https://web.archive.org/web/20150203212209/http://esmeree.com/Terms.html 